\title{
CHINA'S ONE BELT, ONE ROAD AND ENERGY SECURITY INITIATIVES: A PLAN TO CONQUER THE WORLD?
}

\author{
Almir Mustafic \\ International University of Sarajevo
}

\begin{abstract}
In less than 50 years China has grown from a poor country to a global power. Export of goods to the developed markets of the West and the insistence on the Five Principles of Peaceful Co-existence have elevated China to the second largest economy in the world. China's development plans function on a basis of a two-way road and the principle behind it is pretty straightforward, energy import and goods export. The scale of diplomatic efforts to strengthen China's relationships with Asian, African and European countries brings astounding results almost on a daily basis. The Chinese mobile providers in Africa had 475 million users in 2013 and the total trade between China and Africa from rose to US\$198.49 billion by 2012. Chinese success stories are not too different in Asia and Europe, where they invest billions of dollars in various infrastructure projects. In March 2016, China came up with its most ambitious project, outlining a $\$ 50$ trillion plan to create a world electricity network that heavily incorporates wind energy from the Arctic and solar energy from the Equator regions. As the report states, the project could come on line by 2050, but the State Grid wants to begin pilot projects within the next 10 years. This paper analyzes the complexity and multidimensionality of the Chinese plans within and outside the scope of the One Belt, One Road initiative and makes an attempt at predicting one of the possible outcomes of the Chinese plans.
\end{abstract}

Keywords: One Belt, Silk Road, Five Principles of Co-existence, Security, Trade, Asia, Africa, Europe.

\section{INTRODUCTION}

In less than 50 years China has grown from a poor country to a global power. Export of goods to the developed markets of the West and the insistence on the Five Principles of Peaceful Co-existence ${ }^{1}$ have elevated China to the second largest economy in the world. Four of the five largest banks in the world today are Chinese and it is no wonder that China on average invests more than a billion dollars per country, which by all means represents a very serious investment, especially in case of undeveloped and third-world countries.

$1 \quad$ Five Principles of Peaceful Co-existence were originally enumerated by the Chinese leadership in 1954: mutual respect for each other's territorial integrity and sovereignty (changed to mutual respect for each other's sovereignty and territorial integrity at the Asian-African Conference), mutual non-aggression, non-interference in each other's internal affairs, equality and mutual benefit (changed to equality and mutual benefit in the Sino-Indian joint Statement and Sino-Burmese Joint Statement), and peaceful co-existence (http://www.fmprc.gov.cn/mfa_eng/ ziliao_665539/3602_665543/3604_665547/ t18053.shtml). 
Put simply, China's development plans function on a basis of a twoway road and the principle behind it is pretty simple, energy import and goods export. As Payne (2016) puts it, "the oil will continue to flow east and goods will continue to ship west" (p. 2). However, the implementation of such a plan requires unprecedented efforts and a long-term planning. Although the current Chinese development plans are often called 'Silk Road' and perceived as an equivalent of the ancient Silk Road, the following chapters will show that the complexity and multidimensionality of these plans are way beyond the scope of the ancient Silk Road and, besides establishing the economic belt and diversifying energy supplies, Chinese projects also include investments in many other areas. ${ }^{2}$

Chinese initiatives in the field of energy over the past few years have been astounding. The scale of diplomatic efforts to strengthen China's relationships with Asian, African and European countries brings results almost on a daily basis. Over the past few years fifty-three African countries have been given various economic grants, interest-free loans and preferential loans by China and it seems that there is much more to come. The Chinese investment efforts in Central Asia and Asia in general are comparable to those in Africa and they also include renewable energy, natural gas and nuclear energy projects. As a result, not only that China is perceived as an 'energy intruder' into the Central Asian countries by Russia (Eder, 2014) but also as a rising power that is slowly taking over the African continent. Therefore, it is no wonder that China's concerns related with the stability and security of the international supplies is often characterized as an "obsession with the oil problem" (Kambra \& Howe 2007, p. 121).

Following the Chinese oil imports it becomes obvious that countries from which China imports oil are pretty much in line with the One Belt, One Road initiative. In addition, Chinese efforts to secure oil imports and other energy resources extend over the boundaries of the

Inquipy 2016/2 One Belt, One Road initiative and scratching the surface of the Chinese development in Asia, Middle East and Africa, it becomes evident that there is actually much more than meets the eye. China is not only developing and diversifying its oil and gas imports and securing economic routes but also investing in many other projects that are not directly related with energy or the OBOR initiative. Therefore, we may rightly ask whether the Chinese energy security projects, combined with the OBOR initiative, are enough to justify trillions of dollars China is inCanal, etc.), transport, water, healthcare, common identity, mining, telecommunications, construction, tourism, technology, environment, etc. 
vesting in various projects around the world.

The official Beijing has been promoting its projects as economic and trade initiatives but as the Chinese projects are progressing it is becoming more obvious that Beijing is also trying to achieve other goals, such as general security (e.g. control over Xinjiang province) and its long-term geostrategic objectives.

This paper analyzes Chinese demand for oil and the development of the One Belt, One Road (OBOR) initiative announced by the Chinese President Xi Jinping in 2013. Other Chinese initiatives around the world will be touched upon as well. The aim of the analysis is to answer several questions: What is actually the OBOR initiative and how is it connected with the energy security? Why does China need such an extensive network of ports, roads, railways and energy networks in (inland) Asia, Africa and Europe? How are education, healthcare, culture promotion, railway and road construction in Africa connected with the Chinese energy security and economy? Does China really need to include almost every country in Asia and Africa in its project in order to secure its energy supplies and economy? Are these two plans - Chinese oil imports security and diversification and OBOR initiative - besides being economic and energy security plans - also a silent takeover of the leadership position from the US? What is the grand strategy behind the Chinese plans?

\section{CHINA'S OIL AND GAS DEMAND AND IMPORTS}

Crowded streets, people honking the horns, long traffic jams, blackouts and constant obsession with energy security are frequent concerns in China. Only 20 years ago this picture was very different. In the 1990s China's per capita consumption of petroleum was at about 170 $\mathrm{kg}$, which was around $10 \%$ of the level in advanced economies (Kambara \& Howe, 2007). However, according to Hurst's (2006) prediction, China will have 120 million private cars by 2020 , which will increase the demand for oil to 14.2 million $\mathrm{bpd}^{3}$ by 2025 and according to the International Energy Agency (IEA), by 2035 China will probably have 360 million passenger vehicles (Preston, 2011). Therefore, China will be facing severe energy shortages if considerable supplies and new energy sources are not secured. Furthermore, due to 9.85\% GDP annual growth rate from 1989 until 2016 (Husna, 2016), China is already not able to meet its own needs through its domestic production of energy and it is anticipated that by 2030 China will be importing about $85 \%$ of its oil (Preston, 2011). This pace of growth in the demand for energy, China's urbanization and economic rebalancing have set China on a 
road of urgent expansion of energy resources abroad, which will have substantial consequences for the world's energy markets (Poorsafar, 2013) and, according to British Petroleum (BP), China will account for $25 \%$ of growth in total energy demand through 2030 (Poorsafar, 2013).

This rise in the demand for energy is mostly caused by the Chinese economic development plans. Namely, since the 1990s China has been focused heavily on its economic growth and the energy drives that growth. As previously mentioned, China's development plans function on a basis of a two-way road and the principle behind it is pretty simple, energy import and goods export. China has been striving to ensure that its energy sources are not interrupted in the future, as energy security is critical to its growth (Hurst, 2006). The energy security issue, although as a term used since the 1990s, was actually prioritized in the 2000s and in 2003 a "going global" strategy to address this issue became one of the top Chinese priorities (Lee, 2012). The issue started as a solution to the energy and economic issues, but China's approach to its energy security needs is rather strategic and it includes financial, political and diplomatic support to national oil companies to secure foreign supplies for domestic use (Lee, 2012).

Of the world's estimated 1.3 trillion barrels of proven oil reserves, more than half are in the Middle East, with Latin America and North America next in line. Major Middle Eastern oil exporters are Saudi Arabia, Kuwait and Iraq (Lee, 2012) and until 2003 China was importing majority of its oil from the Middle East. Then, due to instability of the region, China shortly shifted the focus on other parts of the world such as Caspian, Russia, the Americas, the East and South China Sea and Africa (Hurst, 2006).

In 2004 China also started intensifying its diplomatic visits to African nations in order to set the stage for future energy projects (Hurst, 2006). Over the past decade China established close diplomatic relations with Africa, giving 53 countries various economic grants, interest-free loans

Inquipy $2016 / 2$ and preferential loans, which resulted in 701.000 bpd imports in 2005, that is, $30 \%$ of total Chinese imports came from Africa (Hurst, 2006). China also concluded significant agreements on oil imports from Nigeria and Angola and in 2006 these two countries were already supplying China with as much oil as Saudi Arabia (Hurst, 2006).

Since the discovery of large oil and gas deposits, the Caspian region has also been attracting more international attention. Over the next 20 years global oil exports from this region will rise to $9 \%$ and gas exports to $11 \%$ (Romanowski, 2014). Another Central Asian country, Kazakhstan, has already become one of the most important Chinese oil suppliers and in 2014 Turkmenistan, with the largest gas deposits 
in Central Asia, was one of the main Chinese suppliers (Romanowski, 2014). According to the current plans, China expects to import up to 65 billion cubic meters of natural gas from Turkmenistan on an annual basis by 2020 and in 2013 China signed an agreement to import up to 10 billion cubic meters of natural gas from Uzbekistan (China's Ambitions in Xinjiang and Central Asia: Part 2, 2013).

In 2014, China also concluded a $\$ 400$ billion gas deal with Russia (Romanowski, 2014). However, due to the global political trends the situation regarding oil imports from Russia is a different story. Although China has for long been importing oil from Russia, a new pipeline (1 million bpd) agreed by both countries will probably not be completed by the end of the decade (Hurst, 2006). Moscow's plan to maximize profits in prolonged negotiations and fear of China's rise combined with the role that energy exports could play in Russian foreign policy and domestic politics seem to be an insurmountable obstacle at the moment (Eder, 2014).

Recognizing the importance of the diversification of its oil imports, China temporarily froze its efforts in Russia and started establishing closer relations with other suppliers. Figures from 2010 show that 23\% of China's offshore equity oil production was in Kazakhstan, 15\% in Sudan and Venezuela, 14\% in Angola, 5\% in Syria, 4\% in Russia, and 3\% in Tunisia, while the remaining 20\% was in Nigeria, Indonesia, Peru, Ecuador, Oman, Columbia, Canada, Yemen, Cameroon, Gabon, Iraq, Azerbaijan and Uzbekistan (Lee, 2012). However, in 2014 together with Saudi Arabia and Angola, Russia was again among the top Chinese oil suppliers. In the same year $30 \%$ of natural gas came to China from foreign sources, while in 2015, Saudi Arabia was still China's largest supplier of crude oil (Daniels \& Brown, 2015).

Another issue related with the energy security is the pollution of environment. Beijing has for long been one of the most polluted cities in the world and this pollution is mostly caused by the coal-based energy production. In order to reduce reliance on coal, the Chinese set a goal of raising the percentage of the total energy mix supplied by clean energy to $15 \%$ by 2020 , while in 2014 Beijing announced a plan to have $20 \%$ of its total energy come from non-fossil fuel sources by $2030,10 \%$ from natural gas by 2020 , as well as the reduction of coal energy to $62 \%$ and expansion of nuclear energy production by 2020 (Tiezzi, 2014c). According to the announced plan, China will be producing $85 \%$ of its total energy by 2020 and, together with all the other projects, the deep-water drilling in the South China Sea will be intensified (Tiezzi, 2014c). In comparison with the above-mentioned predictions from 2011 that China will be importing $85 \%$ of its oil by 2030 , this plan might be a bit 
surprising and the announced reduction in coal consumption means that China will have to find and secure other sources of energy.

On the other hand, it is already known that clean energy sources will probably not be enough to satisfy Chinese demands, which means that China will have to strengthen its diplomatic relations with new energy partners in order to secure crude oil and gas imports. Beijing is aware of this issue and the Chinese diplomats have for long been very active in their international efforts to establish close diplomatic relations with many countries around the world. Therefore, Beijing's investments in over 50 African countries are not at all surprising.

However, international concerns regarding the Chinese economic and energy security plans cause a lot of controversy in the international community. There is a growing distrust that the Chinese economic efforts are actually much wider geo-strategic plans to establish the dominant diplomatic position in many regions of the world. Taking into account Russian fears regarding the Chinese geo-strategic rise, it is also worth mentioning here that, due to Beijing's efforts to establish a political route for its NOCs with host governments, suspicions that energy security is just a sub-component of a broader Chinese geo-strategy is additionally fueled and a fear that the Chinese upstream acquisitions can lock up oil supplies and distort international oil markets to the detriment of other economies is already present at the international level (Lee, 2012).

\section{PROJECTS ALONG THE ONE BELT, ONE ROAD INITIATIVE}

The Chinese One Belt, One Road initiative, also known as the Silk Road Economic Belt, announced in 2013 is probably the most extensive project of the 21 st century. The OBOR project is often described as the most significant initiative that China has ever undertaken. This initiative includes five major goals: policy coordination, facilities connectivity, unimpeded trade, financial integration and people to people bonds (Winter, 2016). As Junjie (2015) says, the Silk Road is more of a net2016/2 work than it is a fixed route that makes its way through the continental. In this sense, Beijing is promoting the OBOR initiative economically, politically, militarily and culturally and it has become China's major foreign policy goal (Li \& Yanzhuo, 2015). Want China Times estimated the total value of the Silk Road Economic Belt at \$21.1 trillion and a new version of the projects reveals many new connecting points including Moscow, Russia; Dushanbe, Tajikistan; Jakarta, Indonesia; and Colombo, Sri Lanka (Tiezzi, 2014c).

As Rudolf claims, the OBOR initiative is Xi Jinping's major project and he promotes it on every state visit. This initiative is intended to cre- 
ate infrastructure networks and expand China's economic and political influence in Eurasia (Rudolf, 2015). As initially presented, China's new Silk Road was supposed to stretch over land from East Asia to western Europe and include sea routes from the Chinese port of Fuzhou to Jakarta, Kalkuta and Colombo in Asia to Nairobi in Africa and Athens and Venice in Europe. However, African continent is becoming increasingly involved in this initiative.

During Foreign Minister Wang Yi's trip to Africa in 2014, he visited Kenya and spoke about China's plan to build a $\$ 3.8$ billion railroad linking Nairobi, Kenya's capital, to Mombasa, a port on the Indian Ocean in order to connect Nairobi to the maritime trading route (Tiezzi, 2015c). Tiezzi points out that this project is supposed to eventually connect Nairobi with the capitals of Uganda, Rwanda, Burundi and South Sudan and that the Chinese Minister also added that China was ready to help Africa link all its capitals by high-speed railways and then to connect all of Africa to China's Silk Road vision. Besides this railroad network, China is also developing ports in Djibouti, Tanzania, and Mozambique and, according to a Bloomberg report citing the Namibian Times, China is also considering ports in Madagascar and the Seychelles (Tiezzi, 2015c). In 2015, China also made an agreement with Thailand to invest in developing 12 ports - including seven African ports (in Djibouti, Tanzania, Mozambique, Gabon, Ghana, Senegal, and Tunisia), and China has already invested in other infrastructure development projects in Africa, constructing roads, railways, and public buildings (Tiezzi, 2015c).

Besides infrastructure, China Daily predicted increased co-operation in the sectors of industry, agriculture, mining, finances, telecommunications and services (Tiezzi, 2014a). Mushahid Hussain, chairman of the Pakistan-China Institute, explained that the economic corridor is crucial for the integration of the 'Greater South Asia' and that it includes China, Iran, Afghanistan and stretches to Myanmar (Tiezzi, 2014a). Yale (2015) also indicates that the OBOR initiative is intended to serve diplomatic, economic, and strategic purposes, as well as, through economic incentives, to cement relationships with countries that are friendly to China such as Malaysia, Cambodia, Sri Lanka, and Pakistan. In this sense, the Maritime Silk Road represents part of a historical continuum, which has been referred to by some as a 'String of Pearls' policy (Yale, 2015).

Yale (2015) also says that, in order to predict what projects China is likely to fund in the future, it is necessary to look at some of the Chinese investments in the past: oil and natural gas links to Myanmar's port in Sittwe, Hambantota and Colombo Port City projects in Sri Lanka, 
and Gwadar port in Pakistan. Malaysia and China, which is already the largest trading partner for most countries in Southeast and South Asia, announced a joint port project in Malacca.

When it comes to the Chinese initiatives in Europe, it is significant to mentioned Xi Jinping's visit from 2014. The Chinese president visited the Netherlands, France, Germany and Belgium and urged the EU and China to combine EU policies with China's OBOR initiative (Tiezzi, 2015d). As Tiezzi emphasizes, Hungary was already the first EU member state to sign a memorandum of understanding with China in 2015 and after this MoU, Russia and Belarus also agreed to work with China on the OBOR project (Tiezzi, 2015d). By 2015, Chinese companies invested more than $\$ 5$ billion in CEE countries in sectors of energy, infrastructure and machinery and in the coming years China will build a high-speed railway between Hungary and Serbia and construct two nuclear reactors at a Romanian nuclear power plant (Tiezzi, 2015d).

In an interview from April 2016 Bakir Izetbegović, President of Bosnia and Herzegovina $(\mathrm{BiH})$, supported the OBOR initiative and said that $\mathrm{BiH}$ is ready for closer relations with China in the area of energy, infrastructure, culture and tourism (Izetbegović dao intervju kineskoj agenciji Xinhua: Kina je dobrodošla da učestvuje u razvoju $\mathrm{BiH}, 2016)$ and in May 2016 Chen Bo, Chinese Ambassador to Bosnia and Herzegovina, confirmed the Chinese interests to invest in Bosnia and added that Beijing is mostly interested in energy, infrastructure, forestry and agriculture (Maslo, 2016). Over the next few years China is planning to invest over $€ 3$ billion in energy projects in Bosnia and Herzegovina and similar projects are planned in Croatia, Kosovo and Montenegro (A.C., 2016).

China also wants to connect all the countries along the OBOR routes by a complex network of roads, rails and pipelines (Sellier, 2016). Beijing promised to invest $\$ 1.4$ billion in port infrastructure in Sri Lanka, $\$ 50$ billion in infrastructure and energy deals in Central Asia, $2016 / 2$ \$327 million in general aid in Afghanistan (railways, highways, water conservancies, power facilities, etc.) (Tiezzi, 2014c). According to Sellier (2016), the new ports built in Sri Lanka, Pakistan, Bangladesh, and Kenya, spreading from the coast of mainland China through the South China Sea, the Strait of Malacca, across the Indian Ocean, and into the Arabian Sea and Persian Gulf provide a basis for the construction of new railways that extend from these ports into the interior of the host countries.

China also bought Piraeus port in Greece in 2016. This port will serve the same purpose and it will be a basis for developing infrastruc- 
ture from Athens to the Balkans and Central Europe. Chinese banks gave considerable loans for Greek ship-owners who agreed to build their new ships in China, while other collaborations include naval research and development programs between the universities of the two countries (Atzori, 2016).

In 2016, China signed investment and aid deals worth billions of dollars with Egypt and outlined multi-billion-dollar investment plans for the wider Middle East. According to the President Xi's statement, China will dedicate $\$ 15$ billion to boost industrial production in the region, $\$ 10$ billion for joint energy projects and another $\$ 10$ billion in soft loans, while together with the UAE and Qatar, China will also invest $\$ 20$ billion in conventional energy (Noueihed \& Abdelaty). As part of this plan, China is planning to buy oil from the region and dedicate $\$ 300$ million to help train the police (Noueihed \& Abdelaty, 2016).

The Egyptian president Sisi said for the press in 2014 that economic and military co-operation between China and Egypt reached unprecedented levels (Noueihed \& Abdelaty, 2016) and in the same interview, Xi explained that 32 Chinese companies were working in the Suez Canal economic zone and that the number will rise to 100 firms with $\$ 2.5$ billion of investments (Noueihed \& Abdelaty, 2016). He added that these two countries are planning to implement 15 projects in electricity, infrastructure and transport with investments that could total $\$ 15$ billion (Noueihed \& Abdelaty, 2016).

In 2015, China concluded 20 co-operation agreements with Pakistan worth $\$ 1.6$ billion that Xinhua ${ }^{4}$ characterized as energy and power projects and education and healthcare. China also signed a $\$ 46$ billion agreement to build a port in Gwadar, Pakistan (Pakistan hands over 2000 acres to China in Gwadar port city, 2015). The goal of this project is to connect Kashgar in the Chinese province of Xinjiang with Gwadar. As part of the project China will finance ( $\$ 1.65$ billion) Karot hydropower project in Pakistan (Tiezzi, 2015e). China and Pakistan said that Gwadar Port, energy, transport infrastructure and industrial co-operation would be four key areas for co-operation (Tiezzi, 2015e).

Although still not so significant, China is also active in the Arctic. According to the research from 2015, the reserves in the Arctic have 100 billion tons of fuel (oil and gas) and it is no wonder that it immediately attracted Chinese attention (Enormous Oil, Gas Reserves Found in Russia's Arctic Region, 2015). China's activities in the Arctic are primarily shaped by scientific and climate considerations, commercial interest in the petroleum, shipping and mineral sectors, as well as diplomatic and legal concerns. China is still positioning itself in the Arctic 
in order to get access to resources and take advantage of strategic, economic, military, and scientific opportunities in the Arctic region (Kuo \& Tang, 2015).

The above-mentioned projects clearly indicate that the OBOR initiative, besides its initially planned routes, is constantly adding new connecting points, but also including projects in various fields that were not part of the original initiative. Therefore, it can be concluded that China's vision of the OBOR initiative seems to be a bit different from just an economic belt. According to some analysts, it already looks more like an establishment of a political community that stretches from Asia to Europe and Africa and, according to Tiezzi (2014b), China is convinced that its principles will be the guiding force in this new community.

\section{MILITARY INITIATIVE}

Although China is promoting non-intervention and non-interference principles, it seems that Beijing in some cases digresses from this course. South China Sea dispute, alleged intervention in Syria, military agreements with Nepal and Egypt and the Djibouti military port are some of the examples of the Chinese non-alliance with its basic international affairs principles.

Although China supplied Assad with weapons in the past (Rudolf, 2016), Beijing has managed to dodge the direct military intervention in Syria for some time (Payne, 2016). However, Beijing's avoidance has also elicited accusations of free riding and ignoring a humanitarian disaster (Payne, 2016). As Payne (2016) points out, China's policy of supporting Assad's government as the legitimate authority in Syria is often criticized, but at least China is not regularly increasing its troops in Syria or trying to intensify the fight against ISIS. Instead, it is working to deepen economic relations with Saudi Arabia, Egypt, and Iran, among others.

However, Beijing has started engaging with both the Syrian government and opposition leaders in an effort to mediate the conflict. China's new approach is based on a mix of geostrategic interests and the desire to be seen as an influential actor on the stage of global diplomacy (Rudolf, 2016). China's Foreign Minister Wang Yi hosted his Syrian counterpart Walid al-Moallem and shortly after this meeting his guest was Khaled Khoja, the president of the National Coalition for Syrian Revolutionary and Opposition Forces (Rudolf, 2016).

In 2016, Israel accused China of sending troops to Syria but it is more likely that Beijing has dispatched military observers — with the approval of the Assad government - as it has done in Iraq before (Rudolf, 2016). It seems that because of the OBOR initiative Beijing's 
concern for the regional security is becoming stronger than its long-promoted non-intervention and non-interference policy. In January 2016, China also sent an envoy to Iran and Saudi Arabia, calling on its oil suppliers to exercise restraint in their diplomatic clash (Rudolf, 2016).

Prior to the Syrian intervention, in 2014, economic and military co-operation between China and Egypt reached unprecedented levels (Noueihed \& Abdelaty, 2016) and in 2016, Nepal and China pledged to increase defense co-operation (Tiezzi, 2016c).

The Chinese military and diplomatic efforts can be perceived through the prism of the OBOR initiative but also through the rising issue with the Uighur people in Xinjiang province. As China extends its energy and mining activities in its western regions, especially in Xinjian province, Beijing will be forced to enhance regional security co-operation and tighten control over its borderlands (China's Ambitions in Xinjiang and Central Asia: Part 2, 2013). A recent dispute between China and India over India's decision to issue a visa to Uyghur activist Dolkun Isa shows how seriously Beijing treats the security issue in its western regions but also how serious Beijing's concerns actually are (Patranobis, 2016). The OBOR initiative is intended to help China get access to resources but also to solve security issues with the Muslim population in western China. Beijing wants to get support and collaborate with the governments of the Central and West Asian countries in order to keep this issue under control and tighten the security on its borders. This plan is also a way of avoiding a direct confrontation with the US rebalance in this region (Wang Z., 2015).

When it comes to the southern and eastern regions of Asia, China managed to form an economic partnership with its long-time adversary, Vietnam and is acting pretty aggressively in South China Sea, especially in the light of its failure to respond to Typhoon Haiyan in Philippines $^{5}$ (Chen, 2013).

In 2015, Beijing signed a 10-year agreement with Djibouti to set up a navy base for ships that would be engaged in anti-piracy operations off the coast of Yemen. This $\$ 100$ million base would be based in the Obock region, from where an American outpost was evicted earlier the same year (Kleven, 2015). There are several reasons why China selected Djibouti for its naval base. According to Kleven, Djibouti is a fairly stable country at the strategic trade route linking the Suez Canal to the Indian Ocean and from this point the Chinese maritime patrol aircraft can cover most of the Arabian Peninsula and northern and central Africa without refueling. Djibouti's port can accommodate Chinese aircraft carriers and it is close to the base from which the US conducts 
drone strikes on al Shabaab and al-Qaeda targets (Kleven, 2015).

This project in Jibouti, but also the South China Sea dispute stirred a lot of concern and criticism. According to Yale, despite the idealistic claims of "peaceful economic development absent political strings", China continues its activities in the South China Sea, turning reefs into islands and constructing runways that could be used by the People's Liberation Army. Also, taking into account the basis in Djibouti and the 'String of Pearls' plan, it is no wonder that many Sinologists question the real intention of the OBOR initiative (Kleven, 2015). As some analysts explain, it could easily turn out to be a military ambition consisting of a series of ports stretching from the South China Sea to Africa's East Coast and looking into the Obock case it is almost certain that the militarization of Chinese-owned ports can happen elsewhere (Kleven, 2015). An alleged Chinese submarine in Colombo in 2015, provoked rumors about the establishment of a Chinese naval base in Maldives, and Pakistan's invitation for China to set up a naval base in Gwadar can be interpreted as indicators that the Chinese are actually not planning just to build commercial ports (Pitlo III, 2015).

\section{IMPLICATIONS FOR THE GLOBAL COMMUNITY}

This section of the paper presents a brief overview of the most important implications of the China's global rise and provides an analysis of implications on several world regions. The implications can be divided into several categories: economic, military, human rights, world leadership and energy. A global economic threat is mostly due to the instability of the energy supply to China, which can start a domino effect and influence other countries around the world. The violation of human rights pertains mostly to the Chinese partnerships with corrupt governments in Africa and Asia. The world leadership issue reflects in the Chinese rising position in the world affairs and reduction of the US role in the world affairs but also in the potentially subordinate position of all the countries along the One Belt, One Road. The energy issue includes the rising Chinese demand for oil and gas and establishment of the global electricity network that can destabilize oil and gas markets and give China the monopoly over the world's electricity supply.

The Middle East has for long been the China's weak spot. The security and political situation in the entire region represents a serious threat to China's energy security and, consequently, a threat to the stability of global markets. According to Daniels \& Brown (2015), over one third of global oil demand growth in 2014 can be ascribed to China, which imports $60 \%$ of its oil, and the Middle Eastern crude oil accounted for over half of the total Chinese imports. In addition, China's low 
oil stockpile capacity is extremely vulnerable to any changes in the demand (Hurst, 2006), while at the same time ISIS threatens to spread to the Central Asian regions that are key to the success of the OBOR initiative (Rudolf, 2015). China also has many issues with the Uighur people who are mostly Muslims in the Xinjiang province and who want their independence (Why is there tension between China and the Uighurs?, 2014). Tarim, the largest inland oil basin in China (Tarim Oilfield, 2004), is located in this province as well, which makes the entire region extremely important to Beijing, especially if the OBOR land routes are taken into account.

China is also making attempts at establishing contacts along the Silk Road in order to develop productivity in each country (Tiezzi, 2014b) and this initiative could bring multiple benefits to China: China will have to invest much less in the future in securing the trade routes, the security concerns will be reduced in case of incidents, China will have multiple allies directly involved in the security restoration process and the Chinese currency will eventually be used more than other currencies (Tiezzi, 2014b). As a matter of fact, China's currency, the renminbi, is already used in Mongolia, Kazakhstan, Uzbekistan, Vietnam, and Thailand and it is only a matter of time when renminbi will be used in other countries along the Silk Road (Tiezzi, 2014b). One of the main reasons for the Russian unprecedented success in oil export to China in 2015 is Moscow's decision to accept the Chinese currency as the means of payment.

However, although the above-mentioned Chinese plans seem logical and beneficial for all the parties involved, there is a rising concern in surrounding countries that China's pursuit of its own national interests could harm them and consequently they have adopted a dual strategy of relying on China economically and on the U.S. for security (Li \& Yanzhuo, 2015).

Another important issue in China is electricity, especially in the western regions of China. Beijing has been making attempts at solving this issue for quite a while and State Grid chairman Liu Zhenya outlined a $\$ 50$ trillion plan to create a world electricity network that heavily incorporates wind energy from the Arctic and solar energy from the Equator regions (Spegele, 2016). As the report states the project could come on line by 2050 , but the State Grid wants to begin pilot projects within the next 10 years (Spegele, 2016). As mentioned above, despite the fact that this grid would facilitate the Chinese initiatives along the OBOR routes, this project could also give China a certain monopolistic position over the governments around the world and significantly change the existing policies regarding the electricity supply. 
The following paragraphs present some of the implications of the Chinese growth on the various regions around the world.

China's engagement in oil production and investment in high risk countries of Africa could add new capacity to the world's strained energy market and additionally drive the prices down. Also, without the investments, technology and expertise that China brings to Africa, some of the countries would be unable to realize the financial gain from oil within their boundaries (Hurst, 2006). However, China's involvement in some of the African countries could contribute to instability by further enabling these countries to violate human rights (e.g. Talisman's oil revenues paid to the Sudanese government were used to buy arms to fight the civil war) and continue corrupt activities (Hurst, 2006). Taking into account China's policy of not interfering with another country's internal affairs, China's growing influence in Africa is counter-productive to western objectives of promoting human rights and abolishing corruption. Doing business with the Chinese companies does not require the same ethical conditions as Western companies, whose activities are monitored by non-governmental organizations and shareholders (Hurst, 2006).

Over the past decade, Beijing has been extensively working on strengthening diplomatic ties with many countries in Africa and, as the number of geological evidence of oil increases, China is becoming more active in this part of the world. In this sense, Angola has already established itself as one of the top Chinese exporters of crude oil and the export to China was $13 \%$ of the total amount of oil China imported in 2014, which is 2\% more than Russia (Cunningham, 2015).

China is also emphasizing historical links between the African continent and China in order to meet its own economic objectives. The frequency of visits by the Chinese officials to Africa has increased significantly over the past few years and Beijing is promoted as a reliable partner that is not interested in lecturing Africa on human rights, governance and corruption (Hurst, 2006). As a result, Chinese mobile providers in Africa achieved 475 million users in 2013 (Wong, 2015), the total trade between China and Africa from 2000 to 2012 rose to US\$198.49 billion (Brautigam, 2013) and countries like Angola and Nigeria are becoming important Chinese oil exporters.

Former Chinese president, Hu Jintao, promoted a three-point proposal on friendly relations, common prosperity and closer co-operation between China and Africa in order to strengthen bilateral ties between China and Africa. The President claimed that no political strings were involved or implied, and added that China and Africa should co-operate more closely on an international level to safeguard the rights and 
interests of developing countries (Hurst, 2006). However, although President $\mathrm{Hu}$ denied political background of the Chinese efforts, his statement can be interpreted as a demand for the African support for the Chinese expansion in Africa by presenting the investment projects as their common interest.

Since 2013, South-East Asia has increasingly looked to China as its main trading partner and America as the prime guarantor of its security. However, there is an increasing perception that power in the region is shifting (Relations with South-East Asia, 2013).

Central Asia and Pakistan have for long been strategic Chinese partners. After Xi Jinping's visit to the Central Asian republics in 2013, energy deals were quickly signed with Kazakhstan, Kyrgyzstan, Turkmenistan and Uzbekistan (Romanowski, 2014) and, according to Tiezzi (2016b), in 2016 China started a new hydro-power plant project on the China-Pakistan Economic Corridor (CPEC), which also includes the world's largest solar plant in Punjab Province and the \$10 billion expansion of the Karachi nuclear power plant. The entire CPEC consists of 21 energy projects and China has already committed $\$ 6.5$ billion to build a new nuclear power plant in Karachi (Tiezzi, 2014a).

Beijing is also paying more attention to the $\mathrm{ASEAN}^{6}$ partners. China has a comparative advantage regarding historic, geographic, and geo-economic terms, and it has also been ASEAN's largest trading partner for six consecutive years since the bilateral free trade agreement (FTA) was launched in 2010 (in 2014, bilateral trade was over $\$ 480$ billion and total Chinese FDI in ASEAN was about $\$ 400$ billion) (Ting, 2016). Chinese President Xi also invested significant efforts to mend China's image in the Southeast Asian states - many of which have concerns over China's actions in the South China Sea (Tiezzi, 2015a). As Tiezzi explained, China and Singapore ${ }^{7}$ agreed to reframe their relationship as "a partnership of all-round co-operation keeping with the times." President Xi proposed a vision of Asian relations which is based on a common sense of Asian identity. "We should never let animosity divide us," Xi said. Xi has made similar calls for Asian unity before, but admitted in this talk that security issues remain "very complicated" (Tiezzi, 2015a).

China and ASEAN have started talking about upgrading their bilateral FTA (Ting, 2016). Over the past two years their relationship was pretty fruitful, especially in the China-Indochina Economic Corridor, with advances in several projects such as the China-Thailand Railway, 
China-Laos Railway, the new Lancang-Mekong Dialogue, Two Corridors Plus One Circle Initiative between China and Vietnam, and the China-Singapore Government-to-Government Project in Chongqing (Ting, 2016).

The major issue for China-ASEAN relations at the moment is the territorial disputes in the South China Sea over the islands claimed in part or in whole by China and Taiwan as well as four ASEAN members: Brunei, Malaysia, the Philippines, and Vietnam (Tiezzi, 2016a). Over the past few years the South China Sea issue has developed in three ways: the balance between great powers (mainly China and the US), the relationship between China and ASEAN, and the disputes between China and ASEAN claimant states. Currently, the ASEAN claimants are behind the scenes while the US is in the center of the stage (Li \& Yanzhuo, 2016). However, China's ties with the members of the ASEAN remain stable and bilateral co-operation will likely deepen in the coming years (Li \& Yanzhuo, 2016). An upgraded version of the ASEAN-China Free Trade Agreement was signed in November, 2015 (Li \& Yanzhuo, 2016). It seems that Beijing does not intend to escalate the disputes, as it might impact the implementation of the OBOR strategy, especially the Maritime Silk Road in Southeast Asia (Li \& Yanzhuo, 2016). China is well aware of this danger and Beijing will probably employ diplomatic efforts to tone down the current tensions with the ASEAN claimants and the US.

During the course of 15 years since China's accession to the WTO the trade between the EU and China have expanded substantially. European populists have used the EU's rising trade deficit with China to accuse Beijing of mercantilism and unfair trade tactics, deliberately excluding reference to the EU's record exports to China, which have created millions of jobs and promoted European welfare. They refused to acknowledge China's support for the EU during the Eurozone crisis, which took the form of direct investments and portfolio investments in sovereign bonds of the EU states under economic distress (Zhiqin, 2016).

According to Tiezzi (2015b), in 2016 Chinese Premier Li Keqiang hosted 16 European leaders in Suhzou for the fourth China-Central and Eastern Europe (CEE) summit (first time in China) which brings together leaders from China and 16 Central and Eastern European states: Albania, Bosnia and Herzegovina, Bulgaria, Croatia, Czech Republic, Estonia, Hungary, Latvia, Lithuania, Macedonia, Montenegro, Poland, Romania, Serbia, Slovakia, and Slovenia.

Central and Eastern Europe will play a crucial role in making sure China's 'Silk Road Economic Belt' reaches its final destination - West- 
ern Europe (Tiezzi, 2015b). Although the EU membership of the 11 CEE countries (formerly Communist countries and now EZ member states) has certainly complicated the co-operation framework in terms of restrictive EU legislation, the leadership in Beijing has not given up on the idea of these states becoming 'lobbyists' for Chinese interests within specific EU institutions (Filippova \& Veleva, 2015).

China is also making a bid to help construct railways, roads, and ports in Europe and signed deals with both Hungary and Serbia to build a high-speed rail line between their capitals, Budapest and Belgrade (Tiezzi, 2015b).

Chinese Premier Li also announced that China will invest in constructing and upgrading port facilities in the Baltic, Adriatic and Black Seas, adding that Croatia, Slovenia, Poland, Latvia and Bulgaria have proposed to strengthen co-operation on port development (Tiezzi, $2015 b$ ). Slovakia expressed its interest in gas pipelines and infrastructure projects (Tiezzi, 2015b).

States like Germany, the UK and the Netherlands managed to expand their trade with China substantially, while more labor-intensive EU states saw their global market shares and GDP falter (Zhiqin, 2016). Very few Europeans acknowledge that China has also saved the EU and the world from the US Internet monopoly (Zhiqin, 2016). In the coming years and in the light of a number of projects in various sectors in ECC, the Chinese presence and influence over some of the EU decisions are expected to rise.

In the light of many territorial disputes since 1962 between China and India (Markey, 2015), it is necessary to clarify that there is no contradiction between India's strengthening its ties with the US while also having a reasonable and open relationship with China (Maini, 2016). Due to increasing potential interests in the OBOR benefits, India is very likely to start working on the establishment of even closer ties with China, especially providing that both countries are BRICS member states.

Although many analysts view the India-China relationship through the prism of security issues and territorial disputes, both countries are now trying to find common ground in a number of areas (Maini, 2016). Recently, both countries seem to have made some progress on the Bangladesh, China, India, Myanmar (BCIM) Corridor, which is an important part of China's One Belt, One Road project (Maini, 2016). India's trade with China, as a proportion of India's trade with all countries, was only 0.2 percent in 1991-92 but rose to 8.7 percent in 2013-14 and since 2008 China has also surpassed the U.S. as India's largest trading partner (Bai, 2015). In 2013-14, India's imports from China were 
valued at $\$ 510$ billion, whereas its exports to China amounted to $\$ 150$ billion (Bai, 2015).

India is now seeking to reach out to Chinese provinces with which it did not have previous links (Maini, 2016). And there are other significant reasons to anticipate greater co-operation between China and India. Sino-Indian collaboration in new multilateral settings - such as the BRICS summits, the Asian Infrastructure Investment Bank, and the Shanghai Co-operation Organization - has the potential to grow deeper and more significant over time (Markey, 2015).

As a result of the late January 2015 summit between President Obama and Prime Minister Modi Beijing begun to show a willingness to urgently discuss the resolution of its $4057 \mathrm{~km}$ contested border with India. A flurry of statements and opinions that have been released in China, discussing a possible resolution to the 60-year-old dispute, suggest changing mindsets in Beijing (Gokhale, 2015). After meeting Modi at the BRICS summit (Modi was recognized as a strong leader to negotiate issues by China), President Xi Jinping became the first leader of a P-5 nation to make a trip to India in September 2014 (Gokhale, 2015).

On the other hand, due to India's increasing role in Southeast Asia, specifically in the South China Sea, many analysts believe that this might be a pressure on their relationship (Maini, 2016). Many strategic analysts in India also believe that China is encircling India and often refer to the China-Pakistan Economic Corridor (CPEC) to support their claims (Maini, 2016). Both countries actively pursue closer ties with each other's traditional adversaries: China with Pakistan and India with Japan. Additionally, as India and China build increasingly capable and expeditionary military forces, their areas of operation will overlap more frequently (Markey, 2015), which may present another security issue.

However, Markey (2015) believes that, although conflict and co-operation are not mutually exclusive in international relationships, the most plausible future scenario is one in which New Delhi and Beijing deepen their commercial ties and co-operate in areas of mutual interest,

Inquipy 2016/2 while remaining distrustful of each other's intentions to warrant diplomatic and military hedging. Besides economic and energy plans that China promotes with the OBOR initiative, there is also an important element of the Chinese international development - culture.

The Silk Road incentive for cultural sector co-operation, that started with the first successful Silk Road world heritage listing in 2014 at a Unesco's annual world heritage meeting, could easily become the most ambitious and expansive international co-operation program for heritage preservation ever undertaken. The total number of sites that could be included in this program is more than 500 (Winter, 2016). 
According to Wang Z, the integration of Asia will not work itself out only through railroads, highways and pipelines; it will also depend on whether Asian countries can build common identity and values (Wang, 2015). Junjie (2015) explains as well that what should be taken into account regarding the grand strategy of the OBOR initiative is not only trade or closer diplomatic ties with neighboring countries but the market for ideas.

According to Polk (2014), China has spent considerable time and energy in the Gulf States promoting soft power and Beijing provided a lot of no-strings funding and scholarships for students, CCTV station to broadcast news in Arabic and established Confucius centers aimed at framing how the youth see China. Recent polls showed that $23 \%$ of Arabs see China ${ }^{8}$ as the preferred global superpower (Polk, 2014).

When it comes to economy, it is important to point out that the Chinese trade in the Middle East grew significantly from 2000 to 2014. China achieved 30\% annual trade growth rate with Saudi Arabia and Kuwait, 26\% with the UAE and Iraq, and 28\% with Iran, while the US trade with the Gulf is declining (Polk, 2014). This shows that the Chinese diplomatic and economic efforts have been very serious and that even the USA, a long-time economic partner of the Middle East, does not seem to be able to follow China.

Polk (2014) points out that Saudi Arabia increased oil exports to China in 2009 and awarded Chinese companies several major projects on healthcare, energy exploration, mining, and railroad construction ( $\$ 2$ billion) and King Abdullah's first state visit after ascending to the throne was to China. In February 2016, Saudi Arabia took over the leading China's top oil exporter position from Russia (Holodny, 2016) and due to this fact Beijing pays a lot more attention to the security in the Middle Eastern regions. The Chinese security efforts are mostly focused on the relations between Saudi Arabia and Iran, both of which have close diplomatic and economic relations with China.

Another important Chinese partner in this region is Iran. According to Al-Jazeera, China imports from Iran 10-15\% of its energy needs and the two countries agreed in 2016 to expand their trade from $\$ 52 \mathrm{bn}$ in 2014 to $\$ 600$ bn over the next ten years (West-wary Iran deepens China ties as sanctions end, 2016). Previously, Iran awarded telecommunications contracts and constructions projects to Chinese companies (Polk, 2014), as well as certain highway construction (China Communications Construction to build Iran's North Highway project, 2015). As Ayatollah pointed out at a meeting with the Chinese officials in 2016 (West-wary Iran deepens China ties as sanctions end, 2016), Westerners 
have never obtained the trust of the Iranian nation, which led to closer diplomatic ties with China. On this occasion Iran and China signed 17 documents to broaden bilateral co-operation in energy, industry, transportation, railways, ports, new technology, tourism and the environment (West-wary Iran deepens China ties as sanctions end, 2016). This bilateral agreement, as well as previous Chinese diplomatic efforts, is a clear sign that China is becoming a significant actor in the Middle East, especially if we take into account that the two countries agreed to co-operate on terrorism and extremism in Iraq, Syria, Afghanistan and Yemen (West-wary Iran deepens China ties as sanctions end, 2016).

China's relations with Russia are rather complex and, according to Eder (2014), Russia perceives China in Central Asia in a way as the EU in case of Ukraine, while on the other hand, China perceives Russia as an unreliable partner in opposing the American unipolarity. However, both China and Russia are well aware of the importance of stable and friendly relations with each other. Also, both countries are BRICS member states and want to reduce the US presence and influence in Asia.

Skalamera (2015) claims that Russia does not have advanced technology to reach its oil deposits in the Arctic and Eastern Siberia and although the Chinese companies are technologically not too much ahead of Russians they can help them develop less complex projects such as those in Western Siberia. However, such projects may put Russia in a position of China's resource appendage and, if the oil prices on the global level do not recover soon, Russia can become China's energy resource satellite state (Skalamera, 2015). Beijing's growing influence in Central Asia undermines an important Russian objective, that is, the monopolistic position among the Chinese Central Asian suppliers (Kuo \& Tang, 2015).

When it comes to the relations between China and the USA, the Council on Foreign Relations published a report in which they stated that "No relationship will be as important to the twenty-first century as the one between the United States, the world's great power, and China, the world's rising power" (Hills, Blair, \& Jannuzi, 2007, p. xi). In 2007, the United States and China had a relationship that was truly unimaginable two generations ago (Hills, Blair, \& Jannuzi, 2007). However, taking into account that the US and China are structurally inclined toward disagreement in maritime disputes (Webster, 2015), it is no wonder that China's rapid economic development accompanied by an enormous and growing trade surplus with the United States, expanding economic and political influence in Southeast Asia, the Middle East, Africa, and Latin America, modernization of its military and a two-decade military budget growth and a robust space program have caused a lot of concern 
on the US part recently (Hills, Blair, \& Jannuzi, 2007).

For the past three decades the U.S. policy toward China remained rooted in the strategic interests commonly known as 'engagement' and through this policy China's relationship with the United States was transformed from near-constant antagonism to dialogue and co-operation (Hills, Blair, \& Jannuzi, 2007). However, the geopolitical terrain, altered by the emergence of China as one of the major powers, is changing and, as China's economic and military power grows, there is considerable uncertainty about its future course (Hills, Blair, \& Jannuzi, 2007).

On the other hand, it seems that the election year in the US slowed down its diplomatic efforts abroad. A new president in the office will tailor the US-China relations over the next four years and one of the presidential candidates, Donald Trump, is planning to change relations between the two countries radically. He will mostly focus on three major issues - trade, security and global leadership. Trump's isolationist foreign policy may pull the US out of its current commitments in international governance, such as the United Nations, which could in turn give China the opportunity to transform itself into a 'game maker' from the current position of a 'player' (Qiu, 2016). Trump is also planning to bring millions of manufacturing jobs back to the United States and he suggested levying a $45 \%$ tariff on Chinese products, in order to ensure a level playing for American workers (Qiu, 2016). This plan could force the US companies to leave emerging markets such as China, which would create market vacuum that would Chinese companies continue filling at an even faster rate (Qiu, 2016).

Trump's plan to withdraw from NATO would probably additionally destabilize Europe and accelerate current growing momentum of the right-wing parties which could, led by protectionism, seriously threaten China's business interests in Europe (Qiu, 2016). His position with the UN might give Beijing the opportunity to assume leadership on this platform as well (Qiu, 2016).

A widely discussed study by the Council on Foreign Relations suggests that the US should chose 'preeminence' over 'predominance' regarding China (Webster, 2015) but in case of Trump this option might not be available. If anything is clear now regarding the US-China relations over the next four years, it is a widely spread certainty among the analysts that a very turbulent era in the US-China relations is coming.

\section{CONCLUSION}

Although some authors might claim that China in its repositioning battle with Russia actually contributes to the re-establishment of the US unipolarity, over the past 20 years China has definitely reduced the 
US dominance around the world. The Chinese international efforts so far have been different from the US but military interventions in Syria and South China Sea are indicators that they could not be based on economic, investment and energy ties only.

As the previous chapters showed, it would be pretty naïve to view the Chinese initiatives through the prism of energy security and trade alone. China is not only investing in the OBOR initiative but also in the local networks, economy and energy sector, as well as in security, healthcare and education. Besides the OBOR initiative, China is also developing foreign markets, preparing them for future 'consumption'. It is very obvious that China is strengthening its diplomatic ties with many countries and the most surprising are its large-scale investment projects in Africa.

China used vacuum of power - many Western companies withdrew from Africa because of high pressure from NGOs because of violation of human rights - in order to establish itself and use infrastructure built by the West.

The analysis shows that the OBOR initiative is not only a project of connecting China with the rest of Asia, Africa and Europe, as presented by Beijing, but also a wider geo-strategic plan to establish the dominant diplomatic position of China in many regions of the world. Chinese efforts to establish a political route for its NOCs with host governments raise suspicions that energy security is just a sub-component of a broader Chinese geo-strategy. Additionally, there is already a widespread fear that the Chinese upstream acquisitions can lock up oil supplies and distort international oil markets to the detriment of other economies.

Beijing's energy security plans and the OBOR initiative are tightly connected with its investments and economic development. The Silk Road initiative is supported by the oil, gas and economic initiatives and in this way the security of the Chinese development plans is guaranteed not only by China but also by all the countries that have at least some benefit from the Chinese projects. In this sense, every country is important and the best example of such a coordinated effort are the Caspian region and Africa.

China is also aware that economic and social interdependence and stability are the key to security and an uninterrupted economic growth and trade. A stable economy and a win-win situation have so far been used as a unifying factor by China. Beijing invests in ports, roads and railways and uses culture and various diplomatic efforts to strengthen the OBOR initiative. China is now trying to strengthen its historic ties with the nations along the OBOR routes and has already invested a bil- 
lion out of planned trillions of dollars in various projects, from healthcare, education and search for the remains of Zheng He's fleet to museums, energy and security. China is trying to translate its investments and trade into building a coalition of states that align their values and foreign policies with those of China at the expense of competitors like the United States (China's Maritime Silk Road Gamble). If this was achieved, Chinese security and dominance over many regions without using their own resources would be almost guaranteed and the OBOR initiative would not only be the Chinese interest but the interest of all the states that benefit from this and other Chinese initiatives. It would also secure China's leadership position and facilitate the Chinese plan to connect East Asia and Western Europe. Beijing, by helping its new 'allies' get stronger, is now building a kind of new super bloc that soon might be able to serve as a counterbalance to NATO but also to many other economic unions.

In the end, the answer to the question who benefits from the Chinese expansion might sound naive but, taking into account the current situation in many countries along the OBOR routes, it seems that the answer is everybody. The only issue that countries joining the OBOR and other Chinese initiatives could face in the future is that whether, by seeking to escape the grip of one superpower, they only fell into the grip of another - China.

\section{REFERENCES}

Li, X., \& Yanzhuo, X. (2015, April 9). How China Can Perfect Its 'Silk Road' Strategy. Retrieved March 5, 2016, from The Diplomat: http://thediplomat.com/2015/04/ how-china-can-perfect-its-silk-road-strategy/

Pitlo III, L. B. (2015, February 17). China's 'One Belt, One Road' To Where? Retrieved May 3, 2016, from The Diplomat: http://thediplomat.com/2015/02/ chinas-one-belt-one-road-to-where/

A.C. (2016, May 6). Kineske investicije u regionu se trebaju preusmjeriti s uglja na obnovljivu energiju i energetsku efikasnost. Retrieved May 6, 2016, from Energetika: http://www.energetika.ba/zastita-okolina/11330-kineske-investicijeu-regionu-se-trebaju-preusmjeriti-s-uglja-na-obnovljivu-energiju-i-energetsku-efikasnost.html

Atzori, G. L. (2016, January 21). Can China's New Silk Road Save the Greek Economy? Retrieved March 19, 2016, from The Diplomat: http://thediplomat. com/2016/01/can-chinas-new-silk-road-save-the-greek-economy/

Bai, L. (2015, July 8). How Can China and India Boost Economic Ties? Retrieved May 6, 2016, from The Diplomat: http://thediplomat.com/2015/07/how-canchina-and-india-boost-economic-ties/ 
Brautigam, D. (2013, September 23). China Africa Ec. and Trade Coop. White Paper 2013. Retrieved April 18, 2016, from The China-Africa Research Initiative: http://www.chinaafricarealstory.com/2013/09/china-africa-economic-andtrade.html

Chen, Y.-J. (2013, December 16). China's Contradictory Foreign Policy. Retrieved March 21, 2016, from The Diplomat: http://thediplomat.com/2013/12/ chinas-contradictory-foreign-policy/

China Communications Construction to build Iran's North Highway project. (2015, October 8). Retrieved March 10, 2016, from World Highways: http://www. worldhighways.com/categories/auctions-equipment-supply-servicing-finance/ news/china-communications-construction-to-build-irans-north-highway-project/

China's Ambitions in Xinjiang and Central Asia: Part 2. (2013, October 1). Retrieved April 15, 2016, from Stratfor: https://www.stratfor.com/analysis/chinas-ambitions-xinjiang-and-central-asia-part-2

Cunningham, N. (2015, July 15). The Battle For China's Oil Market. Retrieved April 18, 2016, from Oil Price: http://oilprice.com/Energy/Crude-Oil/The-BattleFor-Chinas-Oil-Market.html

Daniels, O., \& Brown, C. (2015, September 8). China's Energy Security Achilles Heel: Middle Eastern Oil. Retrieved April 23, 2016, from The Diplomat: http://thediplomat.com/2015/09/chinas-energy-security-achilles-heel-middleeastern-oil/

Eder, T. S. (2014). China-Russia Relations in Central Asia: Energy Policy, Beijing's New Assertiveness and 21st Century Geopolitics. Wiesbaden: Springer Fachmedien Wiesbaden.

Enormous Oil, Gas Reserves Found in Russia's Arctic Region. (2015, October 12). Retrieved May 8, 2016, from Sputnik: http://sputniknews.com/russia/20151012/1028418822/russia-arctic-oil.html

Filippova, L., \& Veleva, I. (2015, October 31). Can Europe Fill the Gap in China-Russia Relations? Retrieved May 8, 2016, from The Diplomat: http://thediplomat. com/2015/11/can-europe-fill-the-gap-in-china-russia-relations/

Gokhale, N. (2015, April 1). An Evolution in China-India Relations? Retrieved May 7, 2016, from The Diplomat: http://thediplomat.com/2015/04/an-evolution-in-china-india-relations/

Hills, C. A., Blair, D. C., \& Jannuzi, F. S. (2007, April). US-China Relations: An Affirmative Agenda, A Responsible Course Report an Independent Task Force. New York: Council on Foreign Relations.

Holodny, E. (2016, February 29). Saudi Arabia is once again China's top oil exporter — but the reason is bad news. Retrieved April 2, 2016, from Business Insider: http://www.businessinsider.com/saudi-gained-back-oil-market-share-in-chinabecause-imports-down2016-2

Hurst, C. (2006, July). China's Oil Rush. Retrieved April 10, 2016, from Institute for the Analysis of Global Security: http://www.iags.org/chinainafrica.pdf 
Husna, R. (2016, April 15). China GDP Annual Growth Rate. Retrieved April 17, 2016, from Trading Economics: http://www.tradingeconomics.com/china/gdpgrowth-annual

Izetbegović dao intervju kineskoj agenciji Xinhua: Kina je dobrodošla da učestvuje u razvoju BiH. (2016, April 20). Retrieved April 20, 2016, from Faktor: http:// faktor.ba/izetbegovic-dao-intervju-kineskoj-agenciji-xinhua-kina-je-dobrodosla-da-ucestvuje-u-razvoju-bih/

Junjie, M. (2015, February 10). The New Silk Road and the Power of Ideas. Retrieved April 27, 2016, from The Diplomat: http://thediplomat.com/2015/02/the-newsilk-road-and-the-power-of-ideas/

Kambara, T., \& Christopher Howe. (2007). China and the Global Energy Crisis: Development and Prospects for China's Oil and Natural Gas. Northampton: Edward Elgar Publishing Ltd.

Kleven, A. (2015, December 8). Is China's Maritime Silk Road A Military Strategy? Retrieved May 4, 2016, from The Diplomat: http://hediplomat.com/2015/12/ is-chinas-maritime-silk-road-a-military-strategy/

Kuo, M. A., \& Tang, A. O. (2015, December 16). China's Arctic Strategy: The Geopolitics of Energy Security. Retrieved March 26, 2016, from The Diplomat: http://thediplomat.com/2015/12/chinas-arctic-strategy-the-geopolitics-of-energy-security/

Lee, J. (2012, October 4). The 'Tragedy' of China's Energy Policy. Retrieved February 20, 2016, from The Diplomat: http://thediplomat.com/2012/10/the-tragedy-ofchinas-energy-policy/

Li, X., \& Yanzhuo, X. (2015, April 9). How China Can Perfect Its 'Silk Road' Strategy. Retrieved March 14, 2016, from The Diplomat: http://thediplomat. com/2015/04/how-china-can-perfect-its-silk-road-strategy/

Li, X., \& Yanzhuo, X. (2016, January 8). A Preview of China-Southeast Asia Relations in 2016. Retrieved May 5, 2016, from The Diplomat: http://thediplomat. com/2016/01/a-preview-of-china-southeast-asia-relations-in-2016/

Maini, T. (2016, March 13). What the US Gets Wrong About India's Relationship With China. Retrieved March 19, 2016, from The Diplomat: http://thediplomat. com/2016/03/what-the-us-gets-wrong-about-indias-relationship-with-china/

Markey, D. (2015, November 30). The Sino-Indian Conflict Scenario. Retrieved April 16, 2016, from The Diplomat: http://thediplomat.com/2015/11/the-sino-indian-conflict-scenario/

Maslo, E. (2016, May 3). Chen Bo: Kineska preduzeća žele poslovati u BiH. Retrieved May 3, 2016, from Dnevni avaz: http://www.avaz.ba/clanak/233670/Arial

Noueihed, L., \& Abdelaty, A. (2016, January 21). China's Xi visits Egypt, offers financial, political support. Retrieved April 7, 2016, from Reuters Canada: http:// ca.reuters.com/article/topNews/idCAKCN0UZ05I

Pakistan hands over 2000 acres to China in Gwadar port city. (2015, November 12). Retrieved April 9, 2016, from The Indian Express: http:/indianexpress.com/ article/india/india-news-india/pakistan-hands-over-2000-acres-to-china-in- 
gwadar-port-city/

Patranobis, S. (2016, April 23). China fumes after India issues visa to Uyghur 'terrorist'. Retrieved April 23, 2016, from Hindustan Times Beijing: http://www. hindustantimes.com/india/china-seething-after-india-issues-visa-to-uyghurterrorist/story-uKjeZnyrRaRCkmBHxIwxaJ.html

Payne, J. (2016, February 17). Is There Wisdom in China's Approach to Syria? Retrieved March 21, 2016, from The Diplomat: http://thediplomat.com/2016/02/ is-there-wisdom-in-chinas-approach-to-syria/

Polk, A. (2014, April 1). China: A Major Power in the Middle East? Retrieved April 24, 2016, from The Diplomat: http://hediplomat.com/2014/04/china-a-majorpower-in-the-middle-east/

Poorsafar, H. (2013, November 18). China's Energy Rebalancing: A New Gazpolitik? Retrieved March 27, 2016, from The Diplomat: http://thediplomat.com/2013/11/ chinas-energy-rebalancing-a-new-gazpolitik/

Preston, F. (2011, February 15). China's Challenges: Energy Security. Retrieved March 20, 2016, from The Diplomat: http://thediplomat.com/2011/02/energy-security/

Qiu, Z. (2016, May 5). President Trump: The View From China. Retrieved May 5, 2016, from The Diplomat: http://thediplomat.com/2016/05/president-trumpthe-view-from-china/

Relations with South-East Asia. (2013, October 19). Retrieved May 5, 2016, from The Economist: http://www.economist.com/news/china/21588081-superpowerotherwise-engaged-china-makes-hay-south-east-asia-being-there

Romanowski, M. (2014, July 3). Central Asia's Energy Rush. Retrieved February 17, 2016, from The Diplomat: http://thediplomat.com/2014/07/central-asias-energy-rush/

Rudolf, M. (2015, September 24). China's 'Silk Road' Initiative Is at Risk of Failure. Retrieved March 20, 2016, from The Diplomat: http://thediplomat. com/2015/09/chinas-silk-road-initiative-is-at-risk-of-failure/

Rudolf, M. (2016, January 25). China's New Era of Diplomacy: Engaging in Syria. Retrieved April 18, 2016, from The Diplomat: http://thediplomat.com/2016/01/ chinas-new-era-of-diplomacy-engaging-in-syria/

Sellier, E. (2016, April 19). China's Mediterranean Odyssey. Retrieved April 19, 2016, from The Diplomat: http://thediplomat.com/2016/04/chinas-mediterranean-odyssey/

Skalamera, M. (2015, February 13). China Can’t Solve Russia’s Energy Technology Trap. Retrieved April 26, 2016, from The Diplomat: http://thediplomat. com/2015/02/china-cannot-solve-russias-energy-technology-trap/

Spegele, B. (2016, March 30). China's State Grid Envisions Global Wind-and-Sun Power Network. Retrieved April 25, 2016, from The Wall Street Journal: http:// www.wsj.com/articles/chinas-state-grid-envisions-global-wind-and-sunpower-network-1459348941

Tarim Oilfield. (2004). Retrieved April 29, 2016, from Oil China: http://www.oilch- 
ina.com/eng/Service-Center/oilfileds/Tarim.htm

Tiezzi, S. (2014, February 20). China, Pakistan Flesh Out New 'Economic Corridor'. Retrieved March 22, 2016, from The Diplomat: http://thediplomat. com/2014/02/china-pakistan-flesh-out-new-economic-corridor/

Tiezzi, S. (2014, May 9). China’s 'New Silk Road' Vision Revealed. Retrieved April 5, 2016, from The Diplomat: http://thediplomat.com/2014/05/chinas-new-silkroad-vision-revealed/

Tiezzi, S. (2014, November 6). The New Silk Road: China’s Marshall Plan? Retrieved March 17, 2016, from The Diplomat: http://thediplomat.com/2014/11/the-newsilk-road-chinas-marshall-plan/

Tiezzi, S. (2015, November 2015). China Seeks to Woo ASEAN Through Singapore. Retrieved May 5, 2016, from The Diplomat: http://thediplomat.com/2015/11/ china-seeks-to-woo-asean-through-singapore/

Tiezzi, S. (2015, November 26). China's 'Belt and Road' Reaches Europe. Retrieved May 3, 2016, from The Diplomat: http://thediplomat.com/2015/11/chinas-beltand-road-reaches-europe/

Tiezzi, S. (2015, January 29). China's 'Maritime Silk Road': Don't Forget Africa. Retrieved April 14, 2016, from The Diplomat: http://hediplomat.com/2015/01/ chinas-maritime-silk-road-dont-forget-africa/

Tiezzi, S. (2015, June 9). China's Silk Road in Europe: Not Just Hungary. Retrieved April 23, 2016, from The Diplomat: http://thediplomat.com/2015/06/chinassilk-road-in-europe-not-just-hungary/

Tiezzi, S. (2015, August 13). The China-Pakistan Economic Corridor Gets Even More Ambitious. Retrieved March 30, 2016, from The Diplomat: http://thediplomat. com/2015/08/the-china-pakistan-economic-corridor-gets-even-more-ambitious/

Tiezzi, S. (2016, March 3). Can Singapore Smooth China-ASEAN Relations? Retrieved March 3, 2016, from The Diplomat: http://thediplomat.com/2016/03/ can-singapore-smooth-china-asean-relations/

Tiezzi, S. (2016, January 13). China Powers up Pakistan: The Energy Component of the CPEC. Retrieved February 10, 2016, from The Diplomat: http://thediplomat.com/2016/01/china-powers-up-pakistan-the-energy-component-of-thecpec/

Tiezzi, S. (2016, April 1). China's \$50 Trillion Plan for a Global Energy Grid. Retrieved April 1, 2016, from The Diplomat: http://thediplomat.com/2016/04/ chinas-50-trillion-plan-to-for-a-global-energy-grid/

Ting, G. (2016, March 16). U.S. Upgrading Economic Ties with ASEAN amid China's Growing Influence. Retrieved March 18, 2016, from China-US Focus: http:// www.chinausfocus.com/finance-economy/u-s-upgrading-economic-ties-withasean-amid-chinas-growing-influence/

Wang, H. H. (2016, January 15). China's Triple Wins: The New Silk Roads. Retrieved January 17, 2016, from Forbes: http:/www.forbes.com/sites/helenwang/2016/01/15/chinas-triple-wins-the-new-silk-roads/\#62ff17e0520b 
Wang, Z. (2015, January 30). China's Alternative Diplomacy. Retrieved April 28, 2016, from The Diplomat: http://thediplomat.com/2015/01/chinas-alternative-diplomacy/

Webster, G. (2015, december 23). 2015: The Year US-China Relations Went Public. Retrieved May 8, 2016, from The Diplomat: http://thediplomat. com/2015/12/2015-the-year-us-china-relations-went-public/

West-wary Iran deepens China ties as sanctions end. (2016, January 24). Retrieved March 5, 2016, from AlJazeera: http://www.aljazeera.com/news/2016/01/ west-wary-iran-warms-china-sanctions-160124054336143.html

Why is there tension between China and the Uighurs? (2014, September 26). Retrieved March 3, 2016, from BBC: http://www.bbc.com/news/world-asia-china-26414014

Winter, T. (2016, March 29). One Belt, One Road, One Heritage: Cultural Diplomacy and the Silk Road. Retrieved April 16, 2016, from The Diplomat: http://thediplomat.com/2016/03/one-belt-one-road-one-heritage-cultural-diplomacy-andthe-silk-road/

Wong, A. (2015, September 21). China's Telecommunications Boom in Africa: Causes and Consequences. Retrieved March 14, 2016, from E-International Relations: http:/www.e-ir.info/2015/09/21/chinas-telecommunications-boom-in-africacauses-and-consequences/

Yale, W. (2015, April 22). China's Maritime Silk Road Gamble. Retrieved March 19, 2016, from The Diplomat: http://thediplomat.com/2015/04/chinas-maritimesilk-road-gamble/

Zhiqin, S. (2016, March 15). China-EU Relations: Crisis and Opportunity. Retrieved March 15, 2016, from The Diplomat: http://thediplomat.com/2016/03/ china-eu-relations-crisis-and-opportunity/ 